\title{
ASYMPTOTIC BEHAVIOR OF POWER MEANS
}

\section{NeVEn Elezović And LenKa MiHoKović}

Abstract. We consider asymptotic behavior of classical $n$-variable means. General expansions of these means are known in the term of Bell polynomials. Here, simple recursive algorithms are derived. The obtained coefficients are used in analysis of some inequalities between means which include the first asymptotic term.

Mathematics subject classification (2010): 26E60, 41A60.

Keywords and phrases: Asymptotic expansion, power mean, asymptotic inequality.

\section{REFERENCES}

[1] U. ABEL, M. IVAn, A complete asymptotic expansion of power means, J. Math. Anal. Appl. 325, 1 (2007), 554-559.

[2] T. Burić, N. Elezović, Asymptotic expansion of Arithmetic-Geometric mean, J. Math. Inequal. 9, 4 (2015), 1181-1190.

[3] C.-P. CHEn, N. Elezović, L. VuKŠić, Asymptotic formulae associated with the Wallis power function and digamma function, J. Class. Anal. 2, 2 (2013), 151-166.

[4] C.-P. CHEN, N. Elezović, L. VUKŠIĆ, Asymptotic expansion of integral mean of polygamma functions, Math. Inequal. Appl. 18, 1 (2015), 255-266.

[5] N. Elezović, Asymptotic inequalities and comparison of classical means, J. Math. Inequal. 9, 1 (2015), 177-196.

[6] N. ElEzović, Asymptotic expansions of gamma and related functions, binomial coefficients, inequalities and means, J. Math. Inequal. 9, 4 (2015), 1001-1054.

[7] N. Elezović, L. VUKŠIć, Asymptotic expansions of bivariate classical means and related inequalities, J. Math. Inequal. 8, 4 (2014), 707-724.

[8] N. Elezović, L. VuKŠIĆ, Asymptotic expansions and comparison of bivariate parameter means, Math. Inequal. Appl. 17, 4 (2014), 1225-1244.

[9] N. EleZOVIĆ, L. VUKŠIĆ, Asymptotic expansions of integral means and applications to the ratio of gamma functions, Appl. Math. Comput. 235 (2014), 187-200.

[10] N. EleZOVIĆ, L. VUKŠIĆ, Neuman-Sandor means, asymptotic expansions and related inequalities, J. Math. Inequal. 9, 4 (2015), 1337-1348.

[11] D. S. Mitrinović, J. E. PeČArić, A. M. Fink, Classical and New Inequalities in Analysis, Kluwer Academic Publishers, Dordrecht, 1993.

[12] V. Timofte, On the positivity of symmetric polynomial functions. Part I: General results, J. Math. Anal. Appl. 284 (2003), 174-190.

[13] F. Zhang, B.-Y. XI, Y.-M. CHU, A new method to prove and find analytic inequalities, Abstr. Appl. Anal. 2010, Art. ID 128934, 19 pages. 